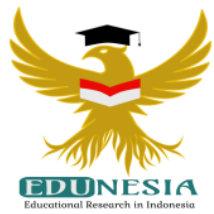

\title{
Implementasi Metode Collaborative Learning Dalam Pembelajaran Statistika Untuk Meningkatkan Keterampilan 4C (Critical and Problem Solving Skills, Collaboration Skills, Communication Skills, And Creativity and Innovation Skills) Pada Siswa Kelas XI
}

\author{
Fitriyanti1; Intan Sukma Laras²; Khuswatun Khasanah³; \\ Ilma Dea Anita ${ }^{4}$; Fadilah Rahmawati ${ }^{5}$ \\ 1,2,3,4,5 Pendidikan Matematika, Universitas Tidar, Indonesia \\ ${ }^{1}$ Corresponding Email: fitriyanti.13ixc@gmail.com, Phone Number : 0858 xxxx xxxx
}

\section{Article History: \\ Received: Dec 02, 2020 \\ Revised: Dec 14, 2020 \\ Accepted: Dec 16, 2020 \\ Published: Jan 01, 2021 \\ Keywords: \\ Ability 4C, Collaborative \\ Learning, Statistics.}

Kata Kunci:

Collaborative Learning,

Kemampuan 4C,

Statistika.

\section{How to cite:}

Fitriyanti, F., Laras, I.S., Khasanah, K., Anita, I.D., \& Rahmawati, F. (2021). Implementasi Metode Collaborative Learning Dalam Pembelajaran Statistika Untuk Meningkatkan Keterampilan 4C (Critical And Problem Solving Skills, Collaboration Skills, Communication Skills, And Creativity And Innovation Skills) Pada Siswa Kelas XI. Edunesia: Jurnal Ilmiah Pendidikan, 2 (1): 249-259.

This is an open access article under the CC-BY-NC-ND license

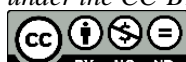

Abstract: The purpose of this research is to improve critical and problem solving skills, collaboration skills, communication skills, and creativity and innovation skills $(4 \mathrm{C})$ in grade XI students in Statistical Learning with the Implementation of Collaborative Learning Methods. The research method used is experimentation, which is divided into two classes namely experimental class and control class. The sample technique we used was probability sampling, the samples taken in this study came from an affordable population of smk N 1 Wanayasa students in grade XI TKJ A and XI TKJ B in the 2020/2021 school year, with each student from the experimental class and control class of 24 students. Thus, the number of samples used was 48 students. Data collection techniques are carried out by giving pretes and postest questions for Statistics material in improving $4 \mathrm{C}$ capability using Collaborative Learning learning models. Test the research hypothesis using t-test and obtained the results of $\mathrm{t}>\mathrm{t}$ table. Therefore, it can be concluded that there is a role of Collaborative Learning learning methods on Statistics material in improving 4C skills. Collaborative Learning methods can be an alternative for teachers in carrying out learning to create an active, effective and not boring learning atmosphere.

Abstrak: Tujuan penelitian ini untuk meningkatkan keterampilan critical and problem solving skills, collaboration skills, communication skills, and creativity and innovation skills (4C) pada Siswa kelas XI dalam Pembelajaran Statistika dengan implementasi metode Collaborative Learning. Metode penelitian yang digunakan adalah eksperimen, yang dibagi menjadi dua kelas yaitu kelas eksperimen dan kelas kontrol. Teknik sampel yang digunakan adalah probability sampling, sampel diambil dalam penelitian ini berasal dari populasi terjangkau siswa SMK N 1 Wanayasa kelas XI TKJ A dan XI TKJ B tahun ajaran 2020/2021, dengan masing masing siswa dari kelas eksperimen dan kelas kontrol 24 siswa. Sehingga, jumlah sampel yang digunakan yaitu 48 siswa. Teknik pengumpulan data dilakukan dengan pemberian soal pretes dan postest untuk materi Statistika dalam meningkatkan kemampuan 4C menggunakan model pembelajaran Collaborative Learning. Uji hipotesis penelitian menggunakan uji-t dan diperoleh hasil $t$ hitung $>t$ tabel. Sehingga dapat disimpulkan, bahwa terdapat peranan metode pembelajaran Collaborative Learning terhadap materi Statistika dalam meningkatkan kemampuan 4C. Metode pembelajaran Collaborative Learning dapat dijadikan alternatif bagi guru dalam melaksanakan pembelajaran untuk menciptakan suasana belajar yang aktif, efektif dan tidak membosankan. 


\section{A. Pendahuluan}

Saat ini tidak dapat dipungkiri bahwa teknologi menjadi pertimbangan utama dalam perkembangan Indonesia. Setiap aspek kehidupan manusia, termasuk bagaimana hal itu bisa membuat percepatan besar dalam mendirikan lebih banyak lagi lingkungan belajar siswa yang baik (Pamungkas dkk., 2020). Perkembangan pesat di era sekarang selain karena adanya arus globalisasi juga tidak terlepas dari peran dan perkembangan matematika di berbagai bidang kehidupan. Untuk dapat menguasai dan menciptakan teknologi baru dan inovatif di masa depan, diperlukan penguasaan matematika yang kuat dari dini. Oleh sebab itu, matematika menjadi salah satu mata pelajaran penting yang harus diajarkan di sekolah, mulai dari jenjang pendidikan dasar sampai jenjang pendidikan tinggi (Kristianti dkk., 2013)

Bidang studi matematika berfungsi untuk mengembangkan logika berfikir siswa dalam menyelesaikan soal-soal operasi hitung bilangan, pecahan, bilangan romawi, dan bangun ruang diharapkan dapat menyelesaikan permasalahan keseharian para siswa pada saat mereka bermain dengan teman sebaya ketika harus menghitung, membandingkan, mengukur dan menaksir (Shafira, 2017). Ada banyak sekali materi yang diperoleh dari bidang studi matematika. Materi ini ada yang tingkatannya, yaitu mudah, sedang hingga sulit. Hal inilah yang membuat siswa menganggap matematika sebagai mata pelajaran yang sulit. Materi yang terlalu banyak, rumus yang terlalu banyak hingga soal yang begitu rumit menjadi momok mengapa matematika "dibenci" oleh siswa. Salah satu mata pelajaran yang dianggap siswa sulit adalah materi Statistika.

Statistika adalah ilmu pengetahuan yang berhubungan dengan cara-cara pengumpulan, penyajian, pengolahan, analisis data serta penarikan kesimpulan (Hadi dkk., 2018). Statistika menunjukkan suatu pengetahuan yang berhubungan dengan caracara pengumpulan fakta, pengolahan, penganalisisan, dan penarikan kesimpulan serta pembuatan keputusan yang cukup beralasan berdasarkan fakta yang ada. Sebagian siswa mengganggap bahwa materi statistika terlalu sulit. Mereka juga harus teliti dan cermat dalam pengolahan data. Selain itu rumus yang ada dalam statistika juga banyak jenisnya sehingga menjadi masalah bagi siswa yang membuat siswa kadang sulit menyelesaikan pemecahan masalah yang ada. Padahal kita tahu salah satu tujuan dari pembelajaran matematika adalah untuk mengembangkan kemampuan penyelesaian dan pemecahan masalah. Terutama dalam pembelajaran materi statistika yang sangat berguna dalam penyusunan model, perumusan hipotesis, pengembangan alat pengambil data, penyusunan rancangan penelitian, penentuan sampel, dan analisis data, yang kemudian data tersebut diinterpretasikan sehingga bermakna.

Pemecahan masalah diartikan sebagai suatu usaha mencari jalan keluar dari suatu kesulitan (Suci \& Rosyidi, 2012). Kemampuan pemecahan masalah matematis adalah suatu tindakan atau proses untuk menyelesaikan masalah menggunakan konsep atau prinsip - prinsip matematika untuk menyelesaikan masalah matematis melalui cara yang sistematis dan rasional (Rezeki, 2019). Kemampuan pemecahan masalah matematis merupakan hal terpenting di dalam pembelajaran matematika di kelas, karena kemampuan pemecahan masalah dapat berguna bagi kehidupan sehari-hari untuk masalah saat ini, ataupun menjadi pengetahuan baru yang dapat digunakan dalam kehidupannya kelak (Rostika \& Junita, 2017). Pada saat seseorang memecahkan masalah, ia tidak sekedar belajar menerapkan berbagai pengetahuan dan kaidah yang telah dimilikinya, tetapi juga menemukan kombinasi berbagai konsep dan kaidah yang tepat serta mengontrol proses berpikirnya (Anwar \& Amin, 2013). 
Dalam masyarakat global, setiap individu harus memiliki empat kemampuan dasar, yaitu : (1) critical and problem solving skills, (2) collaboration skills, (3) communication skills, and (4) creativity and innovation skills. Keempat keterampilan tersebut dikenal dengan sebutan 4C. Critical Thinking and Problem Solving (berpikir kritis dan pemecahan masalah), adalah kemampuan berpikir tingkat tinggi yang tidak hanya menghafal tetapi menggunakan dan memanipulasi materi yang telah dipelajari sesuai situasi yang dibutuhkan. Communication (komunikasi), adalah interaksi sosial antar seseorang yang saling menyampaikan gagasannya. Collaboration (kolaborasi), adalah bentuk kerjasama untuk mencapai tujuan yang diinginkan secara kelompok. Creativity and Innovation (kreativitas dan Inovasi), adalah kemampuan untuk menciptakan sesuatu yang baru baik gagasan atau berupa karya (Marlina \& Jayanti, 2019).

Pembelajaran yang dilakukan dengan keterampilan belajar dan berinovasi 4C menuntut peserta didik untuk mampu memecahkan masalah dengan mencari informasi dan berpikir kritis (Meilani dkk., 2020). Adapun pengembangan definisi dari pemikiran kritis yaitu proses memeriksa secara internal dan mengeksplorasi masalah yang menjadi perhatian, dipicu oleh pengalaman tertentu, yang menciptakan dan mengklarifikasi makna dalam hal diri sendiri dan orang lain, serta yang menghasilkan perubahan perspektif dan hubungan konseptual (Rahmi \& Suparman, 2019). Keterampilan 4C ini sangat dibutuhkan untuk menghadapi perkembangan zaman yang semakin pesat ke depannya terutama pada abad 21. Keterampilan 4C ini juga harus dapat diterapkan dalam pemecahan masalah matematika, salah satunya pemecahan masalah Statistika.

Untuk mengembangkan keterampilan 4C dalam pemecahan masalah matematika, terutama Statistika maka diperlukan suatu metode untuk diterapkan dalam pembelajaran. Metode ini diharapkan dapat mengatasi masalah kesulitan menyelesaikan masalah Statistika. Metode ini harus dapat mencakup keterampilan 4C yang telah disampaikan sebelumnya. Salah satu metode ini adalah dengan metode Collaborative Learning. Pembelajaran dengan metode Collaborative Learning dapat diimplementasikan untuk pengembangan pembelajaran sehingga dapat meningkatkan hasil belajar matematika (Vahlia, 2015).

Menurut (Brodie, 2010) Collaborative Learning merupakan model sebagai suatu proses komunikatif dapat memfasilitasi terjadinya penggabungan antara pengetahuanpengetahuan tersebut sebagai hasil interaksi antara dua atau lebih siswa. Collaborative Learning adalah suatu proses pembelajaran yang dibagi siswanya menjadi beberapa kelompok mempunyai anggota yang saling menyumbangkan informasi, pengalaman, ide, sikap, pendapat, kemampuan, dan keterampilan yang dimilikinya, untuk secara bersamasama saling meningkatkan pemahaman seluruh anggota (Putri \& Silalahi, 2018). Dalam pembelajaran ada hubungan timbal balik atau hubungan saling mengajari. Collaborative Learning merupakan kegiatan belajar melalui kolaborasi antar siswa. Siswa saling belajar melalui teman sebaya dan berbagi pengetahuan. Hal ini menyebabkan terlahirnya ikatan emosional, spiritual, dan empati di antara siswa. Dengan ini dapat kita lihat bahwasanya Collaborative Learning mengedepankan hubungan sosial daripada individual (Purwaaktari, 2015).

Collaborative Learning mengacu pada lingkungan dan metodologi kegiatan peserta didik melakukan tugas umum di mana setiap individu tergantung dan bertanggungjawab satu sama lain (Baroto, 2015). Prinsip yang mendasari model pembelajaran Collaborative Learning adalah kegiatan saling belajar, dan saling berbagi pengetahuan dengan sesama teman sehingga dari kegiatan pembelajaran dengan model 
ini tidak ada siswa yang paling dominan dan tidak ada pula siswa yang tertinggal sendiri. Adapun langkah-langkah Collaborative Learning meliputi tiga tahapan, yaitu (Ulia, 2018) : (1) Tahap persiapan atau perencanaan pembelajaran kolaboratif. (2) Tahap proses pembelajaran kolaboratif. (3) Tahap penilaian pembelajaran kolaboratif.

\section{B. Metode}

Jenis penelitian ini adalah penelitian kuantitatif. Penelitian ini dilakukan di SMK Negeri 1 Wanayasa. Penelitian dilaksanakan pada bulan November 2020. Objek yang diteliti dalam penelitian ini adalah implementasi metode Collaborative Learning dalam pembelajaran Statistika untuk meningkatkan keterampilan 4C.

Populasi dalam penelitian ini adalah kelas XI SMK Negeri 1 Wanayasa sejumlah 48 siswa yang terdiri dari dua kelas yaitu kelas TKJ A sebagai kelas eksperimen yang mana pada kelas ini diberi perlakuan, yaitu model pembelajaran Collaborative Learning dan TKJ B sebagai kelas kontrol yang mana pada kelas ini tidak diberi perlakuan apapun, pembelajaran menggunakan model yang biasa dilakukan yaitu dengan model konvensional. Teknik sampel yang kami gunakan adalah probability sampling, yaitu teknik sampling dimana setiap anggota dari populasi memiliki peluang yang sama. Lebih tepatnya kami gunakan sampling acak sederhana. Pengambilan ini dilakukan berdasarkan frekuensi probabilitas semua anggota populasi.

Pengumpulan data dalam penelitian menggunakan teknik pretes, Collaborative Learning, Presentasi, postes, dan pembandingan kelas. Instrumen yang digunakan adalah soal pretes dan postes, alat tulis, google formulir, Whatsapp, power point, gambar, Handphone.

Adapun tahapan yang dilakukan dalam penelitian ini meliputi: Pretes melalui media google formulir diberikan pada awal pembelajaran kepada kedua kelas untuk mengetahui seberapa pemahaman siswa dalam menyelesaikan masalah terhadap materi Statistika dalam meningkatkan kemampuan 4C sebelum pembelajaran. Setelah diberikan pretes, kelas kontrol melakukan pembelajaran tanpa metode Collaborative Learning, sedangkan kelas eksperimen melakukan pembelajaran menggunakan metode collaborative learning yaitu, pembagian kelompok menjadi empat kelompok dengan masing-masing kelompok mendapatkan materi yang berbeda-beda mengenai materi Statistika. Setelah pembagian kelompok melakukan pembelajaran menggunakan model Collaborative Learning untuk membahas materi yang telah dibagi pada masing-masing kelompok sebelumnya. Kemudian masing-masing kelompok mempresentasikan hasil pembahasan yang telah didiskusikan kepada semua kelompok. Setelah selesai pembelajaran kedua kelas diberikan postes untuk mengukur kemampuan siswa dalam menyelesaikan masalah terhadap materi Statistika dalam meningkatkan kemampuan $4 \mathrm{C}$ setelah pembelajaran.

Data yang diperoleh dalam penelitian ini secara umum dapat dibedakan menjadi dua, yaitu data mengenai penyelesaian masalah terhadap materi Statistika dalam meningkatkan kemampuan 4C tanpa menggunakan metode Collaborative Learning dan data mengenai penyelesaian masalah terhadap materi Statistika dalam meningkatkan kemampuan 4C menggunakan Collaborative Learning. Skor yang diperoleh dari pretes dan postes kemampuan penyelesaian masalah matematika terhadap materi Statistika dalam meningkatkan kemampuan $4 \mathrm{C}$ dikonversi menjadi nilai dengan rentang 0 sampai dengan 100 dan dikelompokkan menggunakan kriteria pada tabel 1 berikut. 
Tabel 1. Kriteria Kemampuan Pemahaman materi Statistika

\begin{tabular}{cc}
\hline Nilai (X) & Kriteria \\
\hline $80 \leq X \leq 100$ & Sangat Tinggi (ST) \\
$65 \leq X \leq 79,99$ & Tinggi (T) \\
$55 \leq X \leq 64,99$ & Sedang (S) \\
$40 \leq X \leq 54,99$ & Rendah (R) \\
$0 \leq X \leq 39,99$ & Sangat Rendah (SR) \\
\hline \multicolumn{2}{l}{ Sumber : (Purwaaktari, 2015) }
\end{tabular}

\section{Hasil dan Pembahasan \\ Kemampuan Pemahaman Materi Statistika}

Hasil penelitian berupa data tentang kemampuan pemahaman materi Statistika dibedakan menjadi dua, yaitu data pretes dan data postes. Data pretes kemampuan pemecahan masalah Matematika siswa pada kelompok eksperimen, dan kelompok kontrol disajikan pada Tabel 2.

Tabel 2.

Data Pretes Kemampuan Pemahaman materi Statistika

\begin{tabular}{lcc}
\hline \multicolumn{1}{c}{ Deskripsi } & KE & KK \\
\hline Mean & 45,42 & 41,20 \\
Median & 45 & 40 \\
Modus & 50 & 45 \\
Nilai tertinggi & 75 & 65 \\
Nilai terendah & 15 & 20 \\
\hline
\end{tabular}

Sedangkan data postes kemampuan pemecahan masalah Matematika disajikan pada Tabel 3.

Tabel 3. Data Postes Kemampuan Pemahaman Materi Statistika

\begin{tabular}{lcc}
\hline Deskripsi & TKJ A & TKJ B \\
\hline Mean & 71,54 & 65,13 \\
Modus & 90 & 75 \\
Median & 79 & 65 \\
Nilai tertinggi & 98 & 85 \\
Nilai terendah & 21 & 43 \\
\hline
\end{tabular}

Tabel 2 dan tabel 3 menunjukkan bahwa semua kelas mengalami peningkatan nilai rata-rata $C$ setelah pembelajaran. Kelas eksperimen mengalami peningkatan nilai rata-rata sebesar 26,12 dan kelas kontrol mengalami peningkatan nilai rata-rata sebesar 23,93. Dengan demikian, kelas eksperimen dan yang menggunakan model collaborative learning mengalami peningkatan nilai rata-rata Kemampuan Pemahaman Materi Statistika yang lebih besar daripada kelas kontrol yang menggunakan model pembelajaran konvensional. 
Hasil pretes dan postes digunakan untuk mengelompokkan siswa dalam kategori berkemampuan sangat tinggi, tinggi, sedang, rendah, dan sangat rendah. Perbandingan persentase siswa yang memenuhi kriteria berkemampuan sangat tinggi, tinggi, sedang, rendah, dan sangat rendah pada kelas eksperimen, dan kelas kontrol berdasarkan hasil pretes dapat dilihat pada Tabel 4.

Tabel 4. Distribusi Frekuensi Hasil Pretes

\begin{tabular}{lcccc}
\hline \multirow{2}{*}{ Kriteria } & \multicolumn{2}{c}{ KE } & \multicolumn{2}{c}{ KK } \\
\cline { 2 - 5 } & F & $\mathbf{0}$ & $\mathbf{F}$ & $\mathbf{\%}$ \\
\hline Sangat Tinggi & 0 & 0 & 0 & 0,00 \\
Tinggi & 4 & 16,67 & 1 & 4,17 \\
Sedang & 3 & 12,50 & 3 & 12,50 \\
Rendah & 9 & 37,5 & 10 & 41,67 \\
Sangat Rendah & 8 & 33,33 & 10 & 41,67 \\
\hline
\end{tabular}

Jika dibuat grafik, maka grafiknya disajikan pada Gambar 1.

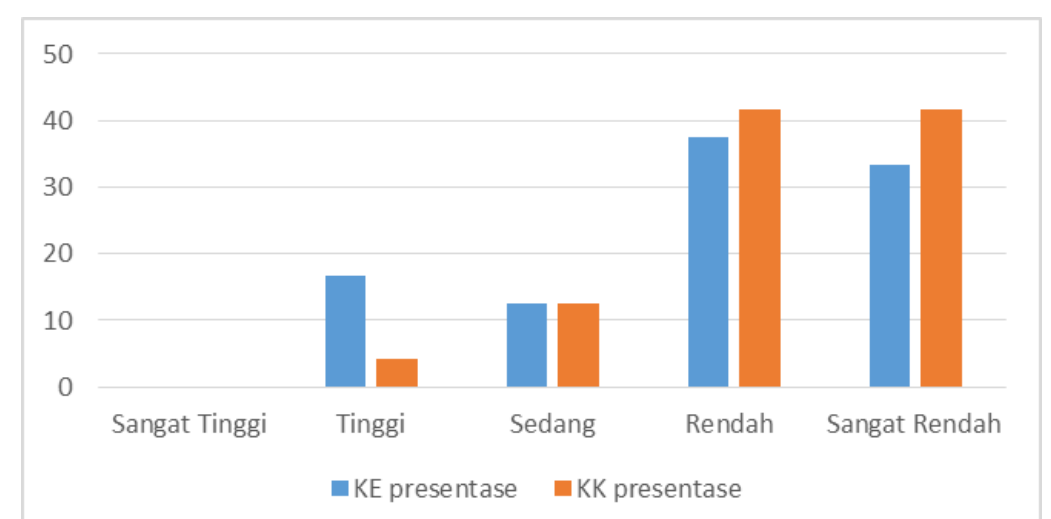

Gambar 1. Persentase Pretes Kemampuan Pemahaman Materi Statistika

Perbandingan persentase siswa yang memenuhi kriteria berkemampuan sangat tinggi, tinggi, sedang, rendah, dan sangat rendah pada kelompok eksperimen 1 , kelompok eksperimen 2, dan kelompok kontrol berdasarkan hasil postes dapat dilihat pada Tabel 5.

Tabel 5. Distribusi Frekuensi Hasil Postes

\begin{tabular}{lcccc}
\hline \multicolumn{1}{c}{ Kriteria } & \multicolumn{2}{c}{ KE } & \multicolumn{2}{c}{ KK } \\
\hline Sangat Tinggi & 12 & 50 & 2 & 8,33 \\
Tinggi & 6 & 25 & 11 & 45,83 \\
Sedang & 1 & 4,17 & 8 & 33,33 \\
Rendah & 0 & 0 & 4 & 16,67 \\
Sangat Rendah & 5 & 20,83 & 0 & 0 \\
\hline
\end{tabular}

Jika dibuat grafik, maka grafiknya ada pada Gambar 2. 


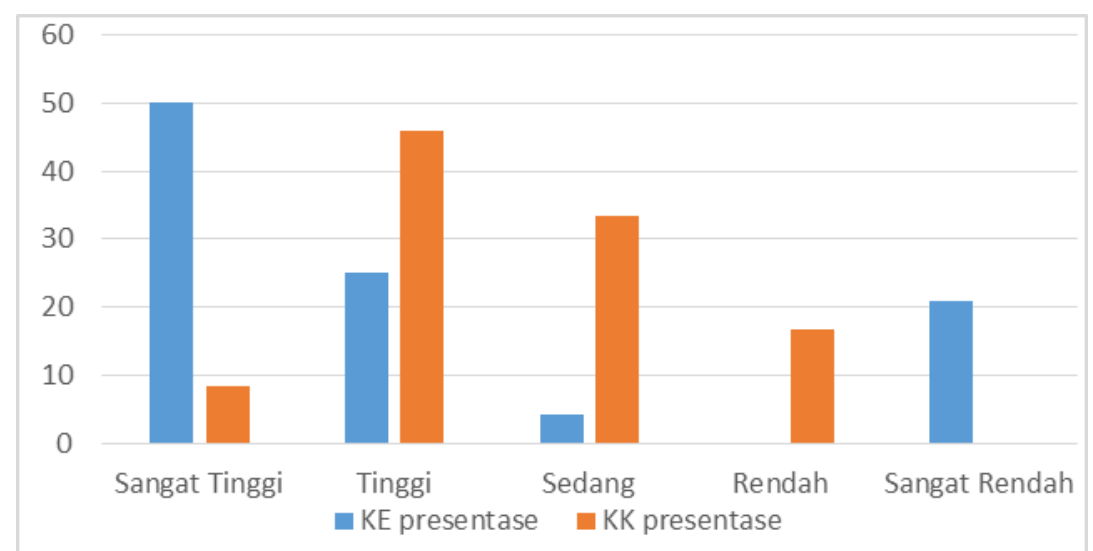

Gambar 2. Persentase Postes Kemampuan Pemahaman Materi Statistika

Gambar 1 dan gambar 2 menunjukkan bahwa kelas eksperimen yang menggunakan model collaborative learning mengalami peningkatan persentase siswa berkemampuan sangat tinggi yang lebih besar daripada kelompok kontrol yang menggunakan model konvensional.

\section{Model Summary}

Tabel 6. Hasil Data Postes Kemampuan Pemahaman Materi Statistika

\begin{tabular}{ccccc}
\hline Model & $\mathbf{R}$ & R Square & $\begin{array}{c}\text { Adjusted R } \\
\text { Square }\end{array}$ & $\begin{array}{c}\text { Std. Error of } \\
\text { the Estimate }\end{array}$ \\
\hline 1 &, $099 \mathrm{a}$ &, 010 &,- 035 & 11,75245 \\
\hline a. Predictors: (Constant), Postes A & \\
\hline
\end{tabular}

Tabel 6 menunjukan bahwa dalam penelitian digunakan model summary. Model ini menjelaskan besarnya nilai korelasi atau hubungan $R$ yaitu sebesar 0,099 . Dari output tersebut diperoleh koefisien determinasi $R$ ( $R$ square) sebesar 0,010 yang mengandung pengertian bahwa pengaruh variabel bebas (Postes $A$ ) terhadap variabel terikat (Postes B) adalah sebesar $1,0 \%$. Nilai $R$ square sebesar 0,010 yang didapat ini menunjukan bahwa keterkaitan antara variabel bebas memiliki pengaruh terhadap variabel terikat. Nilai 0,010 ini telah menunujukan nilai mendekati 1 sehingga keterkaitan antara variabel bebas dan terikat saling berpengaruh. Selanjutnya dilakukan uji untuk membuktikan hipotesis dari penelitian ini.

\section{Hasil Uji Hipotesis}

Data yang digunakan dalam pengujian hipotesis adalah data hasil postes kemampuan pemahaman materi statistika pada kelas eksperimen, dan kelas kontrol. Pada pengujian hipotesis pertama, hasil uji $\mathrm{F}$ digunakan untuk mengetahui apakah kelompok data memiliki varians yang homogen atau tidak. Perhitungan uji F menggunakan Anova dengan kriteria: 1) jika nilai signifikansi lebih dari 0,05 maka data memiliki varians yang homogen, 2) jika nilai signifikansi kurang dari 0,05 maka data memiliki varians yang tidak homogen. Uji F menggunakan bantuan program SPSS 25.0 for windows. Hasil uji $\mathrm{F}$ data hasil postes kemampuan pemahaman materi Statistika kedua kelas disajikan pada Tabel 7. 
Tabel 7. Hasil Uji F Data Postes Kemampuan Pemahaman Materi Statistika

\begin{tabular}{|c|c|c|c|c|c|c|}
\hline ANOV & $\mathbf{A}^{\mathbf{a}}$ & & & & & \\
\hline & & Sum & & Mean & & \\
\hline Model & & Squares & Df & Square & $\mathbf{F}$ & Sig. \\
\hline 1 & Regression & 29,981 & 1 & 29,981 & ,217 & ,646b \\
\hline & Residual & 3038,644 & 22 & 138,120 & & \\
\hline & Total & 3068,625 & 23 & & & \\
\hline
\end{tabular}

a. Dependent Variable: Postes B

b. Predictors: (Constant), Postes A

Tabel 7 menunjukkan bahwa hasil uji homogenitas data postes kemampuan pemahaman materi statistika kedua kelompok memiliki nilai signifikansi yang lebih besar daripada nilai alpha $(0,05)$. Karena nilai signifikansinya lebih besar dari 0,05 maka datadata tersebut memiliki varians yang homogen.

Pada pengujian hipotesis kedua, hasil uji $\mathrm{t}$ data postes kemampuan pemahaman materi statistika antara siswa kelas eksperimen dan kelas kontrol disajikan pada tabel 8 .

Tabel 8. Hasil Uji t Data Postes Kemampuan Pemahaman Materi Statistika

\begin{tabular}{|c|c|c|c|c|c|c|}
\hline \multicolumn{7}{|c|}{ Coefficients ${ }^{a}$} \\
\hline & \multirow[b]{2}{*}{ Model } & \multicolumn{2}{|c|}{$\begin{array}{l}\text { Unstandardized } \\
\text { Coefficients }\end{array}$} & \multirow{2}{*}{$\begin{array}{c}\begin{array}{c}\text { Standardized } \\
\text { Coefficients }\end{array} \\
\text { Beta }\end{array}$} & \multirow[b]{2}{*}{$\mathrm{T}$} & \multirow[b]{2}{*}{ Sig. } \\
\hline & & B & Std. Error & & & \\
\hline \multirow[t]{2}{*}{$\overline{1}$} & (Constant) & 68,763 & 8,168 & & 8,418 & ,000 \\
\hline & Postes A &,- 051 & ,109 &,- 099 &,- 466 & 646 \\
\hline
\end{tabular}

a. Dependent Variable: Postes B

Tabel 8 menunjukkan bahwa koefisien diketahui bahwa nilai constan (a) sebesar 68,763 sedangkan nilai koefisien regresi (b) sebesar -0,051. Konstanta sebesar 68,763 mengandung arti bahwa nilai konsisten variabel partisipasi adalah sebesar 68,763. Koefisien regresi $X$ sebesar $-0,051$. Kenyataan setiap penambahan $1 \%$ nilai Postes $A$, maka partisipasi bertambah sebesar $-0,051$. Koefisien regresi bernilai negatif, sehingga dapat dikatakan bahwa arah pengaruh variabel $\mathrm{X}$ terhadap $\mathrm{Y}$ adalah negative.

Hasil uji $\mathrm{t}$ data postes kemampuan pemahaman materi statistika siswa kelompok eksperimen dan kelompok kontrol memiliki nilai signifikansi 0,646 > 0,05. Karena nilai signifikansinya lebih besar dari 0,05 maka tidak pengaruh. Dengan demikian dapat disimpulkan bahwa terdapat beberapa faktor yang mempengaruhi nilai postes pada kelas eksperimen seperti lemahnya jaringan internet karena tempat pengambilan sampel di daerah yang masih kurang stabil jangkuan internet sehingga mempengaruhi siswa dalam melakukan pembelajaran dengan menggunakan model Collaborative Learning.

Hasil ini berbanding terbalik dengan penelitian yang dilakukan (Purwaaktari, 2015) yang membuktikan bahwa terdapat pengaruh positif dan signifikan penggunaan model collaborative learning terhadap kemampuan pemecahan masalah Matematika 
siswa karena nilai signifikannya kurang dari 0,05 yang artinya ditolak. Sehingga terbukti bahwa terdapat pengaruh positif dan signifikan model collaborative learning terhadap kemampuan pemecahan masalah Matematika siswa

\section{Data Respon Siswa Terhadap Kemampuan 4C}

Hasil penelitian berupa data respon siswa terhadap Pembelajaran Collaborative Learning untuk meningkatkan kemampuan $4 \mathrm{C}$ diperoleh dari angket yang diberikan pada saat akhir pembelajaran. Data respon siswa terhadap kemampuan $4 \mathrm{C}$ disajikan dalam gambar 3.

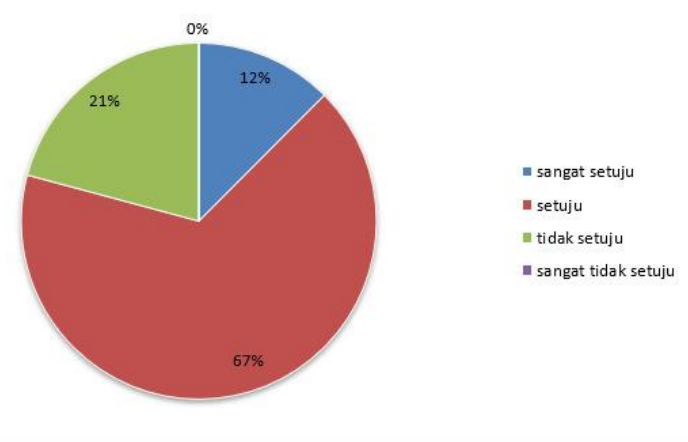

Gambar 3. Data respon siswa terhadap kemampuan 4C

Berdasarkan gambar 3 menunjukan bahwa siswa lebih dominan sejutu dengan presentase $67 \%$ setuju terhadap pembelajaran model Collaborative Learning mampu meningkatkan kemampuan 4C.

\section{Kesimpulan}

Berdasarkan hasil penelitian dan pembahasan dapat disimpulkan bahwa: 1). Kelas eksperimen yang menggunakan model collaborative learning mengalami peningkatan persentase siswa berkemampuan sangat tinggi yang lebih besar daripada kelompok kontrol yang menggunakan model konvensional. 2). Melalui uji Hipotesis menggunakan SPSS 25.0 dihasilkan tidak terdapat pengaruh dan signifikan terhadap model pembelajaran Collaborative Learning dalam kemampuan pemahaman materi Statistika berbanding terbalik dengan penelitian yang dilakukan (Purwaaktari, 2015) yang membuktikan bahwa bahwa terdapat pengaruh positif dan signifikan penggunaan model collaborative learning terhadap kemampuan pemecahan masalah Matematika siswa. 3). Data respon siswa lebih dominan setuju bahwa model pmebelajaran collaborative learning mampu meningkatkan kemampuan $4 \mathrm{C}$.

\section{Saran}

Terkait dengan hasil penelitian, dapat disarankan adalah :

1. Untuk mempelancar sistem daring secara online, sekolah diharapkan memberikan fasilitas kuota gratis agar lebih efektif siswa dalam melakukan pembelajaran secara online.

2. Penelitian ini hanya sebagian cangkupan yakni siswa SMK Negeri 1 Wanayasa dalam pembelajaran Matematika materi Stistika. Oleh karena itu, bagi peneliti selanjutnya, diharapkan dapat memperluas cakupan penelitian khususnya dalam hal pengambilan sampel penelitian agar hasilnya dapat digeneralisasi. 


\section{Daftar Pustaka}

Anwar, S., \& Amin, S. M. (2013). Penggunaan Langkah Pemecahan Masalah Polya Dalam Menyelesaikan Soal Cerita Pada Materi Perbandingan Di Kelas Vi Mi Al-Ibrohimy Galis Bangkalan. Jurnal Pendidikan Matematika E-Pensa, 1(1), 1-6.

Baroto, R. S. (2015). Collaborative Learning Untuk Meningkatkan Pemahaman Ketrampilan Dan Minat Belajar Siswa Dalam Melakukan Instalasi Sistem Operasi Dasar Di Kelas X Tkj 1 Smk Negeri 1 Lumajang. Educazione, 3(1).

Brodie, K. (2010). Teaching Mathematical Reasoning in Secondary School Classrooms. LCC. Springer Science+Business Media.

Hadi, S., Gunawan, I., \& Dalle, J. (2018). statistika inferensial teori dan aplikasinya (kedua). eprints.ulm.

Kristianti, N. K. H., Sudhita, I. W. R. S., \& Riastini, P. N. (2013). Pengaruh Strategi REACT Terhadap Kemampuan Pemecahan Masalah Matematika Siswa Kelas IV SD Gugus XIV Kecamatan Buleleng. Mimbar PGSD, 1.

Marlina, W., \& Jayanti, D. (2019). 4C dalam Pembelajaran Matematika untuk Menghadapi Era Revolusi Industri 4.0. Prosiding Sendika, 5(1), 392-396.

Meilani, D., Dantes, N., \& Tika, I. N. (2020). Pengaruh Implementasi Pembelajaran Saintifik Berbasis Keterampilan Belajar dan Berinovasi 4C terhadap Hasil Belajar IPA dengan Kovariabel Sikap Ilmiah pada Peserta Didik Kelas V SD Gugus 15 Kecamatan Buleleng. Jurnal Elementary: Kajian Teori Dan Hasil Penelitian Pendidikan Sekolah Dasar, 3(1), 1-5.

Pamungkas, M. D., Rahmawat, F., \& Dinara, H. A. (2020). Integrating GeoGebra into Space Geometry in College. 397(Icliqe 2019), 999-1006.

Purwaaktari, E. (2015). Pengaruh Model Collaborative Learning Terhadap Kemampuan Pemecahan Masalah Matematika Dan Sikap Sosial Siswa Kelas V Sd Jarakan Sewon Bantul. Jurnal Penelitian Ilmu Pendidikan, 8(1), 95-111.

Putri, H., \& Silalahi, J. (2018). Pengaruh Model Pembelajaran Collaborative Learning Tipe Jigsaw Terhadap Hasil Belajar Mekanika Teknik Siswa Kelas X Dpib Smk N 1 Koto Xi Tarusan. Cived, 5(4).

Rahmi, A., \& Suparman. (2019). Analisis kebutuhan modul dengan pendekatan ctl untuk meningkatkan motivasi belajar dan keterampilan 4c pada peserta didik. Prosiding Sendika, 5(1), 121-126.

Rezeki, R. A. (2019). Peningkatan Kemampuan Pemecahan Masalah Matematis Melalui Metode Pembelajaran Thinking Aloudpair Problem Solving (Tapps) Pada Siswa Smp. In repository.ar-raniry. Universitas Islam Negeri Ar-Raniry Darussalam Banda Aceh. 
Rostika, D., \& Junita, H. (2017). Peningkatan Kemampuan Pemecahan Masalah Siswa Sd Dalam Pembelajaran Matematika Dengan Model Diskursus Multy Representation (Dmr). EduHumaniora | Jurnal Pendidikan Dasar Kampus Cibiru, 9(1), 35-46.

Shafira, I. (2017). Penerapan Model Collaborative Learning Dalam Peningkatan Pembelajaran Matematika Siswa Kelas Iv Sekolah Dasar.

Suci, A. A. W., \& Rosyidi, A. H. (2012). Kemampuan Pemecahan Masalah Matematika Siswa Pada Pembelajaran Problem Posing Berkelompok. MATHEdunesa, 1(2).

Ulia, N. (2018). Efektivitas Colaborative Learning Berbantuan Media Short Card Berbasis It Terhadap Pemahaman Konsep Matematika. Jurnal Ilmiah Pendidikan Dasar, 5(2), 68.

Vahlia, I. (2015). Perbandingan Penggunaan Metode Collaborative Learning Dan Discovery Learning Terhadap Hasil Belajar Siswa Kelas Vii Smp Darul Arafah Ira. Jurnal Pendidikan Matematika FKIP Univ. Muhammadiyah Metro, 4(2), 53-60. 